\title{
Comparative analysis of albedo and surface energy balance of a grassland site and an adjacent Scots pine forest
}

\author{
Jutta Rost*, Helmut Mayer \\ Meteorological Institute, University of Freiburg, Werderring 10, 79085 Freiburg, Germany
}

\begin{abstract}
The climate conditions in the atmospheric boundary layer are influenced by the underlying land-use type because of its impacts on surface energy balance. Furthermore, the performance of atmospheric models depends crucially on a realistic representation of surface processes, e.g. the partitioning of available energy into individual energy-balance components. The present study investigates the similarities and differences in the energy balance of grassland and forest. Data from the period March 1992 to September 1996 were gathered at 2 adjacent sites in the southern Upper Rhine Plain in southwest Germany: a Scots pine Pinus sylvestris L. forest site at Hartheim, and an adjacent grassland site at Bremgarten. The experimental sites constituted a segment of the REKLIP (Regio-Klima-Projekt) network of energy-balance stations. Synoptic conditions were very similar for both land-use types owing to the short distance between the 2 sites. Differences in available energy $(A E)$ between both land-use types were mainly caused by their different albedo. On average, $A E$ of the Scots pine forest was higher than that for grassland by $24 \%$. Normalised by $A E$, the mean sensible heat flux $H$ accounted for $38 \%$ of the $A E$ for grassland and $47 \%$ of the $A E$ for the Scots pine forest, while the mean latent heat flux $L E$ reached $62 \%$ for grassland and only $53 \%$ for the Scots pine forest. Compared to the mean Bowen ratio $\beta$ of 0.61 for grassland, the relatively high mean $\beta$ value of 0.89 for the Scots pine forest resulted from the strong stomatal control of the pine trees due to the warm and dry site conditions. In the case of a sufficient water supply, forest $A E$ was converted in equal proportions to $L E$ and $H$, while for grassland, 60 and $40 \%$ of $A E$ were converted to $L E$ and $H$, respectively. With a low water supply, more $A E$ was converted into $H$ for both land-use types.
\end{abstract}

KEY WORDS: Energy balance $\cdot$ Land-use types $\cdot$ Grassland $\cdot$ Forest $\cdot$ Pinus sylvestris

\section{INTRODUCTION}

Climatic consequences of changes in land-use type are of major interest worldwide, e.g. because of the varying potential of different vegetation species to uptake $\mathrm{CO}_{2}$. Since forests can store large amounts of $\mathrm{CO}_{2}$, thus helping to counter the climate-change process, afforestation and reforestation are assessed positively in the Kyoto Protocol. However, model results indicate that the storage potential of forests for $\mathrm{CO}_{2}$ is limited (Schaphoff 2006), i.e. afforestation results in a short-term reduction of $\mathrm{CO}_{2}$ but cannot impede climate change in the long term (Read et al. 2001). On the other hand, reliable forecasts over long time periods are difficult because of the various feedbacks between atmosphere and biosphere as well as the difficulties in fully understanding plant physiological processes and possible adaptations of these processes to future climate conditions (IPCC 2000).

In addition to this biogeochemical effect, changes in land-use type have a direct physical impact on processes and phenomena within the atmospheric boundary layer caused by alterations of the aerodynamic surface parameters and surface properties that are relevant for the terms of the energy balance (Bounoua et al. 2002, Tchebakova et al. 2002); that is, 
vertical profiles of air temperature, humidity or wind speed strongly depend on the underlying land-use type.

There is a lack of comparative investigations of the energy balance of different land-cover types (e.g. grassland vs. forests), that are based on long-term measurements of meteorological variables at 2 adjacent sites. Wicke \& Bernhofer (1996) analysed the energetic behaviour of the 2 sites in southwest Germany that are investigated in this study, but only on the basis of an intensive 2 wk measurement campaign characterised by clear-sky weather. Kessler \& Jaeger (1999) compared the radiative fluxes between the forest site of this study and a grassland site near Hamburg (in northern Germany). However, sites which are far away from each other are influenced by different synoptic conditions. It is therefore difficult to extract weather-independent energy differences from the synoptic differences when analysing radiative fluxes of such sites. Recently, further studies have dealt with the analysis of the long-term energy balance of various land-use types (Tchebakova et al. 2002, Yamazaki et al. 2004, Stiller et al. 2005).

The objective of this study was to further investigate differences in energy balance terms between forest and grassland with special emphasis on Scots pine Pinus sylvestris L., which is typical of comparatively dry sites under warm and dry climate conditions. Because the sites were adjacent to one another, problems of comparability of weather conditions were avoided. In addition, the results are not limited to specific weather conditions, since the data covers a continuous period of $>4 \mathrm{yr}$.

\section{MATERIALS AND METHODS}

\subsection{Experimental sites}

Meteorological data were recorded at 2 adjacent experimental sites: Bremgarten (shortcut grassland) and Hartheim (Scots pine forest), which are located in the southern Upper Rhine Plain, about $25 \mathrm{~km}$ southwest of the city of Freiburg in southwest Germany.

The Bremgarten site $\left(47^{\circ} 54^{\prime} \mathrm{N}, 7^{\circ} 37^{\prime} \mathrm{E}_{\text {; }} 212 \mathrm{~m}\right.$ a.s.l. $)$ was set up and maintained within the framework of REKLIP (Regio-Klima-Projekt), a regional climate project carried out from 1991 to 1996 (Kalthoff et al. 1999). The surface was covered by short-cut grass with the fetch exceeding $400 \mathrm{~m}$ in the main wind direction (SSW) and at least $150 \mathrm{~m}$ in all other directions. The surrounding landuse types were grassland and agriculture. There were no significant inhomogeneities or obstructions in close proximity to the site. The instrumentation used at Bremgarten is listed in Table 1. All probes were scanned every $10 \mathrm{~s}$. For the scientific data analysis, 10 min mean values of the meteorological parameters (10 min totals for precipitation), were available.

The permanent forest meteorological site Hartheim $\left(47^{\circ} 56^{\prime} \mathrm{N}, 7^{\circ} 36^{\prime} \mathrm{E}\right.$; $201 \mathrm{~m}$ a.s.l; for details see Mayer et al. 2000) has been operated by the Meteorological Institute of the University of Freiburg since 1974. It is located within a Scots pine forest Pinus sylvestris L. about $3.1 \mathrm{~km}$ northwest of the Bremgarten site and $1 \mathrm{~km}$ east of the River Rhine. The major objective of the continuous recording of meteorological data at the Hartheim site is the long-term analysis of interactions between the growth dynamics of Scots pine forest and its radiation, heat, water and momentum balances (Imbery

Table 1. Instrumentation at Bremgarten (grassland) and Hartheim (Scots pine) sites. a.g.l.: above ground level

\begin{tabular}{|c|c|c|c|c|}
\hline \multirow{2}{*}{ Component } & \multicolumn{2}{|c|}{ Height (m a.g.l.) } & \multirow[t]{2}{*}{ Instrument } & \multirow[t]{2}{*}{ Type, manufacturer } \\
\hline & Scots pine & Grassland & & \\
\hline Short-wave radiative fluxes & 16.0 & 2.0 & Pyranometer & $\begin{array}{l}\text { CM11, Kipp\&Zonen } \\
\text { CM5, Kipp\&Zonen }\end{array}$ \\
\hline Net radiation & 16.0 & 2.0 & Net radiometer & LXG005, Dr. Lange \\
\hline Air temperature, humidity & $\begin{array}{c}2.0,9.9,12.3,15.4 \\
19.5,23.5,29.2\end{array}$ & $10.0,2.0$ & Psychrometer & $\begin{array}{c}\text { Pt-100, Meteorol. Inst. } \\
\text { Univ. Freiburg (like Lambrecht) }\end{array}$ \\
\hline Wind speed & $\begin{array}{c}12.1,15.5,19.1 \\
23.6,29.4\end{array}$ & 10.0 & Cup anemometer & $\begin{array}{l}\text { WAA 15, Vaisala } \\
\text { K100, Lambrecht }\end{array}$ \\
\hline Wind direction & 30.0 & 10.0 & Wind vane & $\begin{array}{l}\text { W200P, Campbell Scientific } \\
\text { Friedrichs }\end{array}$ \\
\hline Soil heat flux & -0.03 & -0.03 & Heat flux plate & CN3, Middleton Solar \\
\hline Precipitation & 21.0 & 1.0 & $\begin{array}{l}\text { Tipping bucket } \\
\text { Ombrometer }\end{array}$ & $\begin{array}{c}\text { ARG100, Campbell Scientific } \\
\text { Thiess }\end{array}$ \\
\hline Soil moisture & 0.0 to -0.3 & & Gravimetric samples & \\
\hline Data acquisition & $\checkmark$ & $\checkmark$ & Micrologger & CR21X, Campbell Scientific \\
\hline
\end{tabular}


Table 2. Characteristics of the Hartheim Scots pine forest site before and after the thinning in autumn 1993. LAI: leaf area index, $P A I$ : plant area index, $h$ : mean stand height

\begin{tabular}{|lcc|}
\hline & 1992 & 1994 \\
\hline Density $\left(\right.$ trees $\left.\mathrm{ha}^{-1}\right)$ & 3750 & 1540 \\
$h(\mathrm{~m})$ & 11.5 & 12.3 \\
Projected $L A I\left(\mathrm{~m}^{2} \mathrm{~m}^{-2}\right)$ & 3.28 & 2.07 \\
Projected PAI $\left(\mathrm{m}^{2} \mathrm{~m}^{-2}\right)$ & 3.93 & 2.47 \\
Overground biomass $\left(\mathrm{kg} \mathrm{m}^{-2}\right)$ & 12.0 & 7.9 \\
\hline
\end{tabular}

2005, Wellpott et al. 2005). The Hartheim area is a highly uniform flood plain. The approximate dimensions of the forest are $10 \mathrm{~km}(\mathrm{~N}-\mathrm{S})$ by $1.5 \mathrm{~km}(\mathrm{E}-\mathrm{W})$. The height of the tower was chosen to obtain a relationship of tower height to fetch of 1:100 for SSW and N wind directions, and a minimum tower height to fetch relationship of 1:30 in E-W directions, which is sufficient for energy-balance studies. Due to thinning in autumn 1993, the stand density, mean stand height $h$, projected leaf area index $(L A I)$, plant area index $(P A I)$ and the overground biomass were reduced (Table 2).

The soil, which is of similar consistency at both investigation sites, is a 2-layer calcaric regosol. The upper layer consists of sandy loam with a mean depth of $0.4 \mathrm{~m}$ ( 0.15 to $0.8 \mathrm{~m})$ and the underlying layer is alluvial gravel. Absolute mean water storage capacity of the upper layer is $80 \mathrm{~mm}$, field capacity is $31.4 \mathrm{vol} \%$ and the permanent wilting point is 11.7 vol\% (Hädrich 1979).

The instrumentation used at the Hartheim site is listed in Table 1. All measurements within and above the canopy were carried out by means of a $30 \mathrm{~m}$ meteorological tower. Vertical profiles of air temperature and humidity were obtained from measurements at 4 levels above the forest as well as 1 level below the canopy (2.0 $\mathrm{m}$ above ground level [a.g.l.]), 1 within the canopy (9.9 $\mathrm{m}$ a.g.l.), and 1 near the mean stand height (12.3 $\mathrm{m}$ a.g.l.). The wind speed was measured at 4 levels above the forest and near the mean stand height. A datalogger scanned all probes every $30 \mathrm{~s}$ and performed the aggregation of the raw data to $1 \mathrm{~h}$ mean values and $1 \mathrm{~h}$ totals (precipitation).

All measured meteorological parameters were subjected to a comprehensive data-quality control, which included different statistical and physical methods (e.g. Grubbs test, extreme values, Lagrange interpolation). The data quality control is explained in detail by Rost (2004).

\subsection{Energy balance}

The energy balance $\left(\mathrm{W} \mathrm{m}^{-2}\right)$ of a flat surface covered with grass can be described as follows (Stull 1988, Flanagan et al. 2002, Stiller et al. 2005):

$$
A E=Q^{*}-G=H+L E
$$

where $A E$ is the available energy, $Q^{*}$ is the net allwave radiation, $G$ is the soil heat flux, $H$ is the sensible heat flux, and $L E$ is the latent heat flux. Compared to shortcut grassland, forests have a high vertical extension. Therefore, the storage heat flux $J$ within the stand has to be taken into account in the energy balance of a forest (Garrat 1992):

$$
A E=Q^{*}-G-J=H+L E
$$

In this investigation $J\left(\mathrm{~W} \mathrm{~m}^{-2}\right)$ was determined according to Oliphant et al. (2004):

$$
J=\rho_{\mathrm{a}} C_{\mathrm{p}} \frac{\Delta T_{\mathrm{a}}}{\Delta t} \cdot \Delta z_{1}-\rho_{\mathrm{a}} L \frac{\Delta q}{\Delta t} \cdot \Delta z_{1}-\rho_{\text {bio }} C_{\text {bio }} \frac{\Delta T_{\text {bio }}}{\Delta t} \cdot \Delta z_{\text {bio }}
$$

where $\rho_{\mathrm{a}}$ is air density $\left(\mathrm{kg} \mathrm{m}^{-3}\right), C_{\mathrm{p}}$ is specific heat of the air at constant pressure $\left(\mathrm{J} \mathrm{kg}^{-1} \mathrm{~K}^{-1}\right), \Delta T_{\mathrm{a}} / \Delta t$ is the temporal variation of the air temperature $T_{\mathrm{a}}\left(\mathrm{K} \mathrm{s}^{-1}\right)$ (mean value of the air temperature at $2.0 \mathrm{~m}$ and $12.3 \mathrm{~m}$ a.g.l.), $\Delta z_{1}$ is the vertical distance between the reference height $z$ and $\Delta z_{\text {bio }}(\mathrm{m})$ - the vertical extent of the projected biomass, i.e. relation of biomass to density of biomass (Schott 1980, Vogt et al. 1996), L is the heat of evaporation $\left(\mathrm{J} \mathrm{kg}^{-1}\right), \Delta q / \Delta t$ is the temporal variation of the specific humidity $q\left(\mathrm{~s}^{-1}\right)$ (mean value of the specific humidity at $2.0 \mathrm{~m}$ and $12.3 \mathrm{~m}$ a.g.1.), $\rho_{\text {bio }}$ is the density of the biomass $\left(\mathrm{kg} \mathrm{m}^{-3}\right), c_{\text {bio }}$ is the specific heat of the biomass $\left(\mathrm{J} \mathrm{kg}^{-1} \mathrm{~K}^{-1}\right), \Delta T_{\mathrm{bio}} / \Delta t$ is the temporal variation of the biomass temperature $T_{\text {bio }}\left(\mathrm{K} \mathrm{s}^{-1}\right)$ (assumed to be equal to the mean value of the soil temperature at $1 \mathrm{~cm}$ depth and air temperature at $2.0 \mathrm{~m}$ and $12.3 \mathrm{~m}$ a.g.1.).

As the turbulent fluxes of sensible and latent heat were not measured directly at the 2 experimental sites, parameterisations had to be used. Since most such approaches have limitations, 3 different methods have been used in this study. The Bowen ratio energy balance (BREB) method is based on the Bowen ratio $\beta$ $\left(H_{\mathrm{BREB}} / L E_{\mathrm{BREB}}\right)$ and the assumption that the exchange coefficients for sensible and latent heat are equal. $H_{\mathrm{BREB}}$ and $L E_{\mathrm{BREB}}$ can be calculated by:

$$
\begin{aligned}
H_{\mathrm{BREB}} & =\frac{\beta}{1+\beta} A E \\
L E_{\mathrm{BREB}} & =\frac{1}{1+\beta} A E
\end{aligned}
$$

$\beta$ depends on $c_{\mathrm{p}}$ and $L$, and on the vertical gradients of $T_{\mathrm{a}}$ and $q$ :

$$
\beta=\frac{c_{\mathrm{p}} \frac{\delta T_{\mathrm{a}}}{\delta z}}{L \frac{\delta q}{\delta z}}
$$

The second method was to derive $L E$ from the actual evapotranspiration and to determine $H$ as the residual 
term of the energy balance equation. LE was calculated in this study according to the Penman-Monteith ( $L E_{\text {P.-M. }}$ ) formula modified by Rana \& Katerji (1998):

$$
L E_{\text {P.-M. }}=\frac{L \times E T P_{\text {Pen }}}{1+[\gamma /(\gamma+\Delta)] \times\left[\frac{r_{\mathrm{s}}}{r_{\mathrm{a}}}\right]}
$$

where $E T P_{\text {Pen }}$ is the potential evaporation according to Penman (mm), $\gamma$ is the psychrometric constant (hPa), $\Delta$ is the slope of the curve of the saturation vapour pressure at the corresponding air temperature $T_{\mathrm{a}}\left(\mathrm{hPa} \mathrm{K}^{-1}\right)$, $r_{\mathrm{s}}$ is the stomata resistance $\left(\mathrm{s} \mathrm{m}^{-1}\right)$, and $r_{\mathrm{a}}$ is the aerodynamic resistance $\left(\mathrm{s} \mathrm{m}^{-1}\right)$. Instead of $r_{\mathrm{s}}$ the bulk stomata resistance, which corresponds to the canopy resistance $r_{\mathrm{C}}$ has been used. Following Köstner et al. (1996) and Rost (2004), the canopy resistances for grassland $\left(r_{\mathrm{C}, \mathrm{g}}\right)$ and the Scots pine forest $\left(r_{\mathrm{c}, \mathrm{f}}\right)$ were estimated as a function of the net all-wave radiation $Q^{*}\left(\mathrm{~W} \mathrm{~m}^{-2}\right)$ :

$$
\begin{gathered}
r_{\mathrm{C}, \mathrm{g}}=\left[-0.547+0.011 \times Q^{*}\right]^{-1} \\
r_{\mathrm{C}, \mathrm{f}}=\left[-0.3082+0.0144 \times Q^{*}\right]^{-1}
\end{gathered}
$$

The aerodynamic resistance $r_{\mathrm{a}}$ was determined according to Troufleau et al. (1997) and Lhomme et al. (2000):

$$
r_{\mathrm{a}}=\frac{\ln \left[(z-d) / z_{0}\right]-\Psi_{\mathrm{H}}(\zeta)}{\kappa \times u}
$$

where $z_{0}$ is the dynamic roughness length (m), $d$ is the displacement height $(\mathrm{m}), \Psi_{\mathrm{H}}$ is the integrated stability function for heat, $\zeta$ is the Monin-Obukhov stability parameter, $\kappa$ is the von Karman constant, and $u$. is the friction velocity $\left(\mathrm{m} \mathrm{s}^{-1}\right)$.

The third method to determine $H$ and $L E$ was a bulk approach. In this study the iteration scheme by Launiainen \& Vihma (1990) was used:

$$
H_{\text {bulk }}=\rho_{\mathrm{a}} \cdot C_{\mathrm{p}} \cdot C_{\mathrm{H}} \cdot U \cdot\left[T_{\mathrm{a}}\left(z_{2}\right)-T_{\mathrm{a}}\left(z_{1}\right)\right]
$$

where $C_{\mathrm{H}}$ is the transfer coefficient for sensible heat, $U$ is the horizontal wind speed $\left(\mathrm{m} \mathrm{s}^{-1}\right)$, and $T_{\mathrm{a}}$ is the air temperature $\left({ }^{\circ} \mathrm{C}\right)$ at the heights $z_{1}$ and $z_{2}$. LE bulk was determined as the residual flux.

The atmospheric stratification was implemented into the transfer coefficient $c_{\mathrm{H}}$ by including the integrated stability functions $\Psi_{\mathrm{H}}$ (heat) and $\Psi_{\mathrm{M}}$ (momentum) according to Beljaars \& Holtslag (1991) for the stable case, and Businger et al. (1971), as well as Dyer (1974), for the unstable case:

$$
c_{H}=\frac{\kappa^{2}}{\left[\ln \left(z / z_{0}\right)-\Psi_{M}(\zeta)\right] \cdot\left[\ln \left(z / z_{t}\right)-\Psi_{H}(\zeta)\right]}
$$

\subsection{Mean weather and climate conditions}

Compared with the mean climate in Central Europe, the climate in the southern Upper Rhine Plain can be characterised as relatively warm and dry. At the Bremgarten weather station, which is close to the Bremgarten grassland site, the mean annual air temperature was $9.8^{\circ} \mathrm{C}$ and the mean annual precipitation was $667 \mathrm{~mm}$ in the period 1951-1980 (see Mayer et al. 2000). Anomalies of mean monthly air temperature and precipitation from March 1992 to September 1996 at the Bremgarten grassland site were compared with long-term means (1951-1980) at the Bremgarten weather station in order to characterise the mean weather conditions during the investigation period (Fig. 1). They reveal warm winter months, whereas most of the transition months were cold and wet compared to the long-term mean. In summer, the weather was frequently cold and dry.

\section{RESULTS}

\subsection{Radiative fluxes}

The downward short-wave radiation $K \downarrow$ represents the main component of the available energy. Owing to the low horizontal distance between both sites, $K \downarrow$ was nearly equal for the Scots pine forest (Fig. 2) and the grassland site. The upward short-wave radiation (or the albedo a) showed remarkable differences between both land-use types, which was also found in previous investigations (Stull 1988). Over the period of investigation, a of grassland (23\%) was on average about twice as high as that of the Scots pine forest $(11 \%)$, which agrees well with previously published albedo values for both land-use types (e.g. Stull 1988, Betts \& Ball 1997, Stiller et al. 2005). Since the weather conditions were almost equal at both sites, different optical features of both land-use types must have been the main cause of this difference. The more pronounced surface structure of the Scots pine

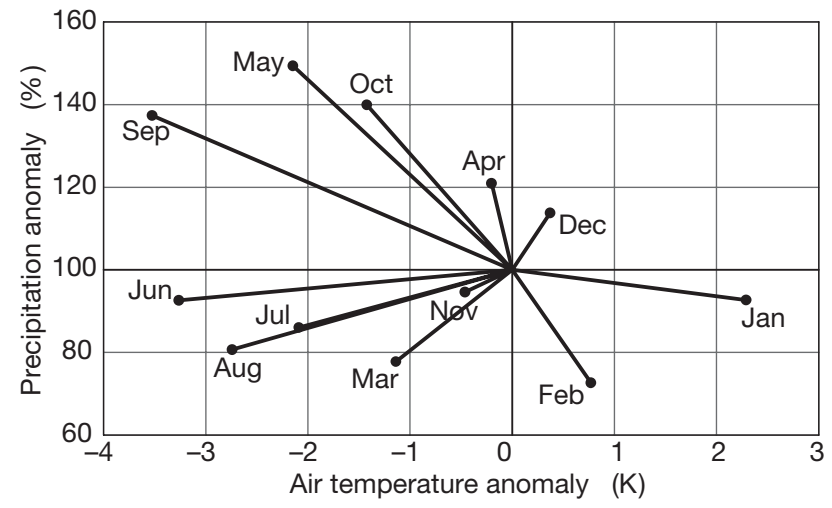

Fig. 1. Anomalies of mean monthly air temperature and mean monthly precipitation in the period March 1992 to September 1996 at the Bremgarten grassland site, based on long-term means (1951-1980) at the adjacent Bremgarten weather station 


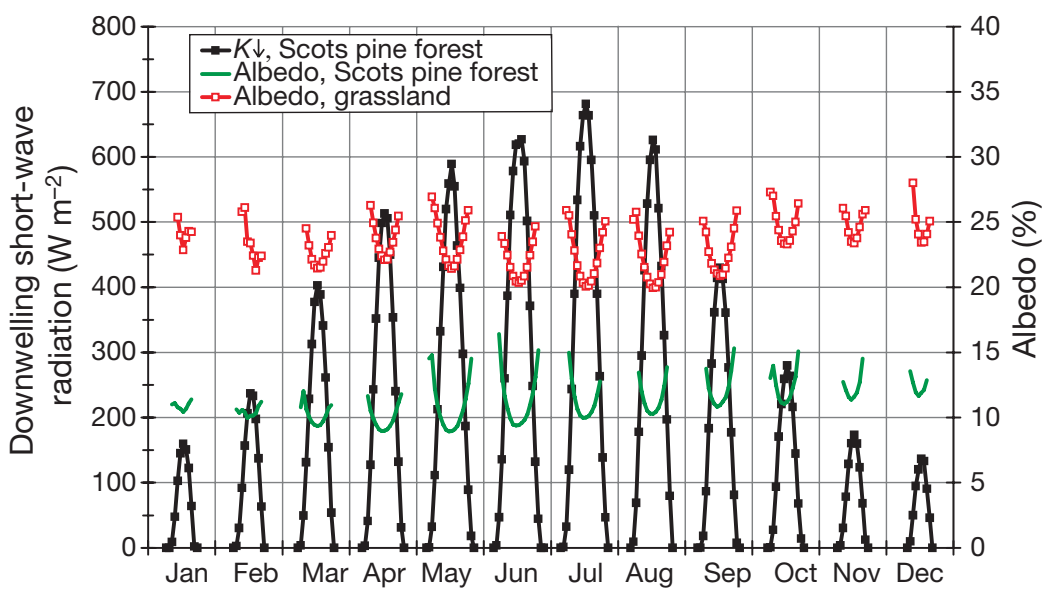

Fig. 2. Monthly means of diurnal variation of downward short-wave radiation $(K \downarrow)$ and albedo for the Scots pine site, and of the albedo of the adjacent grassland site during March 1992 to September 1996

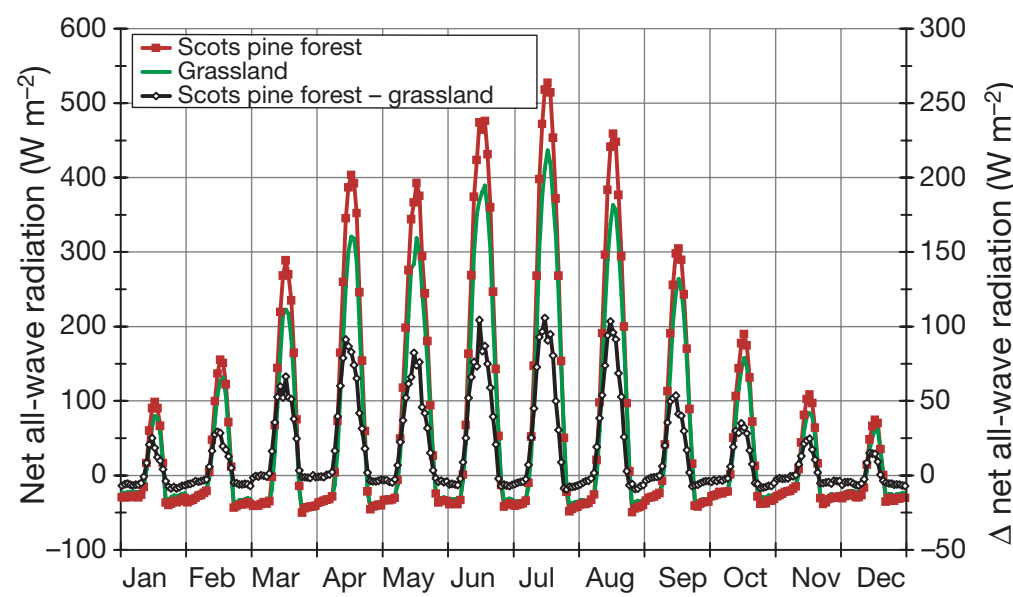

Fig. 3. Monthly means of diurnal variation of net all-wave radiation of adjacent Scots pine forest and grassland during March 1992 to September 1996

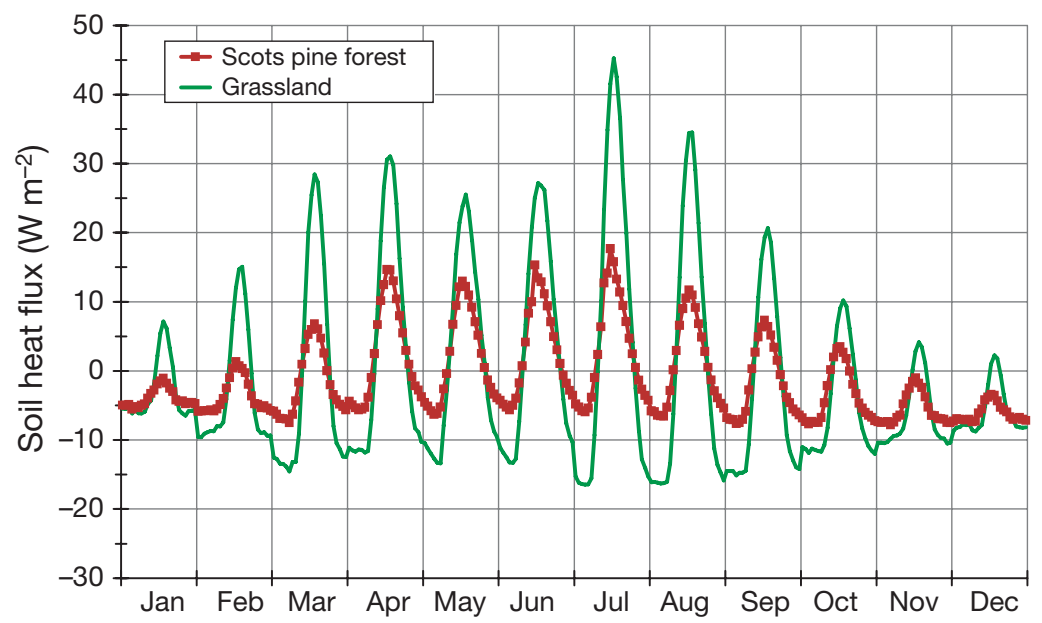

Fig. 4. Monthly means of diurnal variation of soil heat flux of adjacent Scots pine forest and grassland during March 1992 to September 1996 forest led to stronger multiple reflection and scattering of the downward short-wave radiation than at the grassland site (Wicke \& Bernhofer 1996, Kessler \& Jaeger 1999). As a consequence of its lower albedo, the Scots pine forest had a corresponding higher net short-wave radiation than the grassland site (Rost 2004).

In addition to the different $a$ values, the land-use types differed in the upward long-wave radiation $(L \uparrow)$ values. Rost (2004) showed that monthly means of $L \uparrow$ were slightly higher for grassland in summer and for Scots pine forest in winter. Averaged over the full period of investigation, $L \uparrow$ were similar between both land-use types. Mainly due to the increased net short-wave radiation, $Q^{*}$ of the Scots pine forest reached higher mean hourly values in daytime throughout the year (Fig. 3), whereas during the night $Q^{*}$ was slightly higher for grassland because of the lower $L \uparrow$ values (Wicke \& Bernhofer 1996, Rost 2004). Averaged over the period of investigation, $Q^{*}$ reached $66 \mathrm{~W} \mathrm{~m}^{-2}$ for the Scots pine forest and $51 \mathrm{~W} \mathrm{~m}^{-2}$ for the grassland site, i.e. mean $Q^{*}$ was $23 \%$ higher for the Scots pine forest than for grassland.

\subsection{Soil and storage heat fluxes}

Since the soil conditions at both sites are comparable, the differences of the soil heat flux $G$ at both land-use types depends on mean weather conditions and the energy input indicated by $K \downarrow$. The mean daily amplitude of $G$ per month was more pronounced for grassland than for the Scots pine forest (Fig. 4). The dampening effect of the forest was mainly caused by the radiative properties of the forest canopy (i.e. higher absorption of short-wave radiation during the daylight hours). Therefore, mean daily maxima and minima of $G$ reached higher absolute values at the grassland site. For the Scots pine forest, mean hourly values of $G$ were negative from November to January, indicating heat transport from the soil to the surface of the forest floor. 


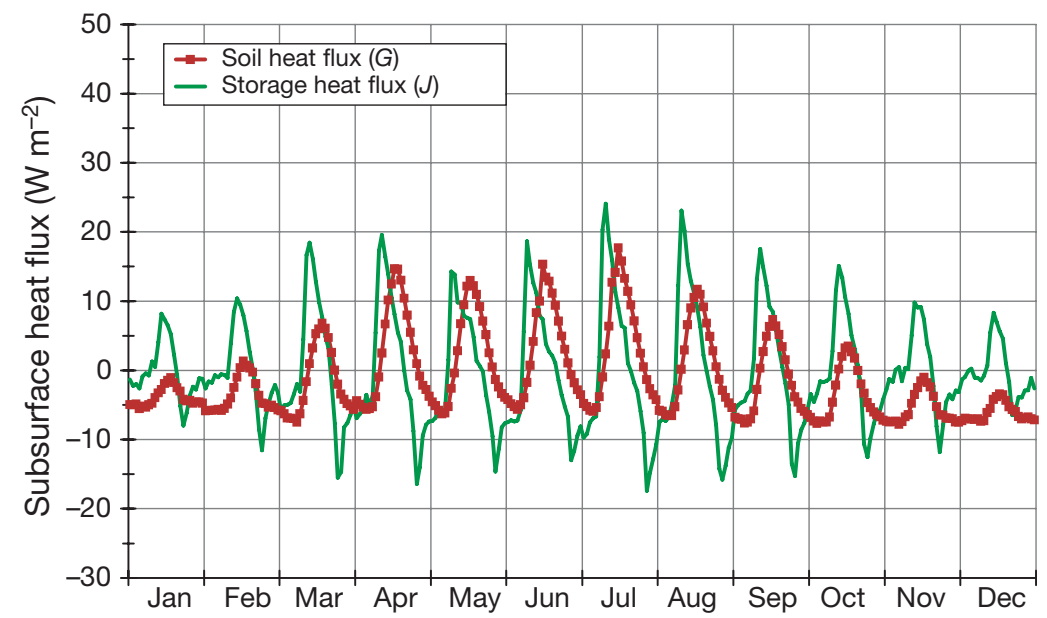

Fig. 5. Monthly means of diurnal variation of soil and storage heat flux ( $G$ and $J$, respectively) of Scots pine forest during March 1992 to September 1996

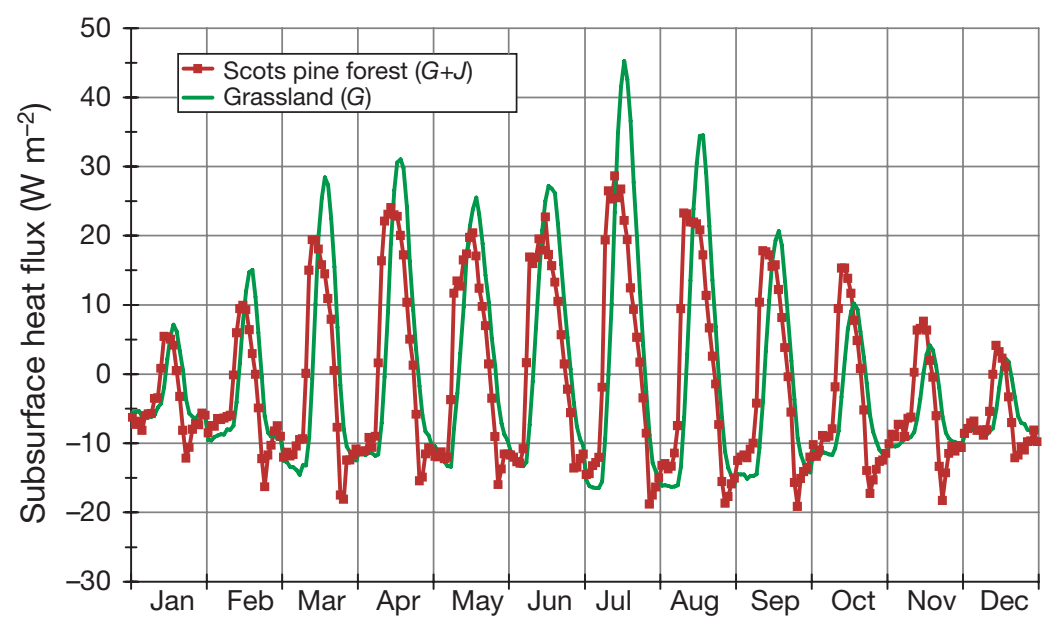

Fig. 6. Monthly means of diurnal variation of the sum of soil and storage heat flux of Scots pine forest and soil heat flux of the grassland site during March 1992 to September 1996

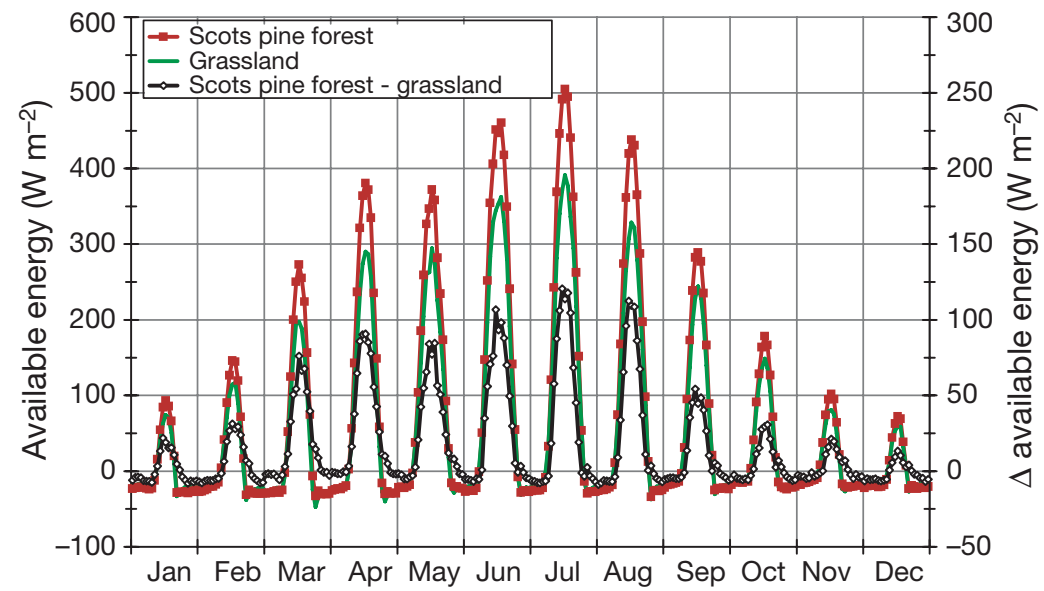

Fig. 7. Monthly means of diurnal variation of available energy of Scots pine forest and grassland during March 1992 to September 1996
The mean daily courses of the soil heat flux $G$ and the storage heat flux $J$ at the forest site are displaced in phase (Fig. 5) since the changes in air and biomass temperature as well as in humidity, that control $J$ (Eq. 3) are most pronounced in the morning hours in contrast to the radiative fluxes, which are the main steering parameters for $G$. With respect to the mean peak values, $J$ exceeded $G$ during all months. A comparison between the sum of $G$ and $J$ for the Scots pine forest and $G$ for grassland (Fig. 6) still reveals the phase displacement, since $G$ for the grassland is mainly determined by the downward short-wave radiation. Apart from October to December, the mean daily maxima of $G$ for grassland were higher than the mean daily maxima of ( $G$ $+J$ ) for the Scots pine forest. During the night, however, the sum of $G$ and $J$ for the Scots pine forest had slightly higher peak values than $G$ for grassland.

\subsection{Available energy}

Compared to $Q^{*}$ (Fig. 3), the $A E$ was slightly more reduced at the grassland site than in the Scots pine forest (Fig. 7). Significant $A E$ differences between both land-use types only occurred during daytime due to the different albedo of the 2 surfaces. During night-time, both sites showed similarly low $A E$ values. A regression analysis of hourly mean values of $K \downarrow$ and $A E$ led to the following results:

$$
\begin{array}{ll}
A E_{\mathrm{f}}=0.71 K \downarrow_{\mathrm{f}}-21.3 & R^{2}=0.965 \\
A E_{\mathrm{g}}=0.55 K \downarrow_{\mathrm{g}}-17.2 & R^{2}=0.963
\end{array}
$$

The relationships show that the Scots pine forest (subscript f) was more effective in the utilization (represented by $A E$ ) of the energy input (represented by $K \downarrow$ ) than grassland (subscript $g$ ).

\subsection{Turbulent heat fluxes}

To investigate the sensitivity of the 3 different methods that were used to determine the turbulent heat fluxes, hourly mean values of the sensible 
heat flux $H$ were calculated for the period 14 to 22 May 1992, which was within the period of the HartX measurement campaign (Wicke \& Bernhofer 1996). The application of the BREB method sometimes failed because of the Ohmura (Ohmura 1982), or error propagation, criteria. For clear-sky weather conditions, the residual flux $\left(H_{\mathrm{P} .-\mathrm{M}}\right)$ of the available energy $A E$ and $L E_{\mathrm{P} . \mathrm{M} \text {. corresponds well with } H_{\mathrm{BREB}}}$ (Fig. 8), whereas the sensible heat flux was slightly underestimated by the bulk approach $\left(H_{\text {bulk }}\right)$, particularly over the grassland. The slope of the regression line between $H_{\text {bulk }}$ and $H_{\text {BREB }}$ was 0.6 for grassland and 0.9 for the Scots pine forest.

To allow for an analysis of the turbulent heat fluxes over both land-use types, the 3 methods were com-

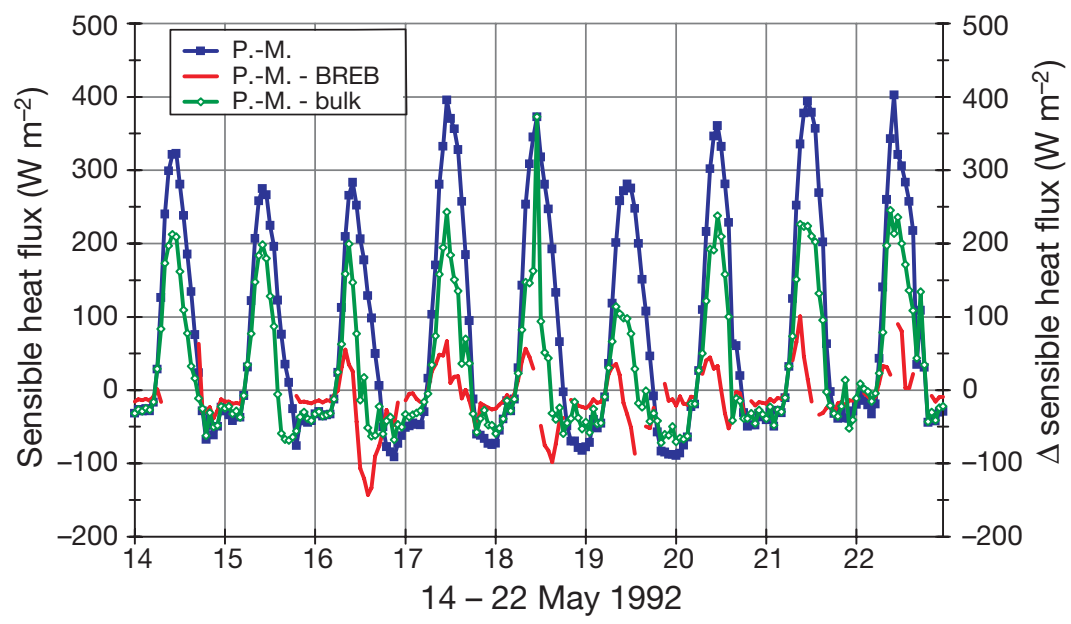

Fig. 8. Daily courses of sensible heat flux $H$ of Scots pine forest. Determined as residual between available energy and latent heat flux derived from the Penman-Monteith equation (P.-M.) as well as differences of $H$ determined according to the BREB method (P.-M. - BREB) and by use of a bulk approach (P.-M. - bulk)

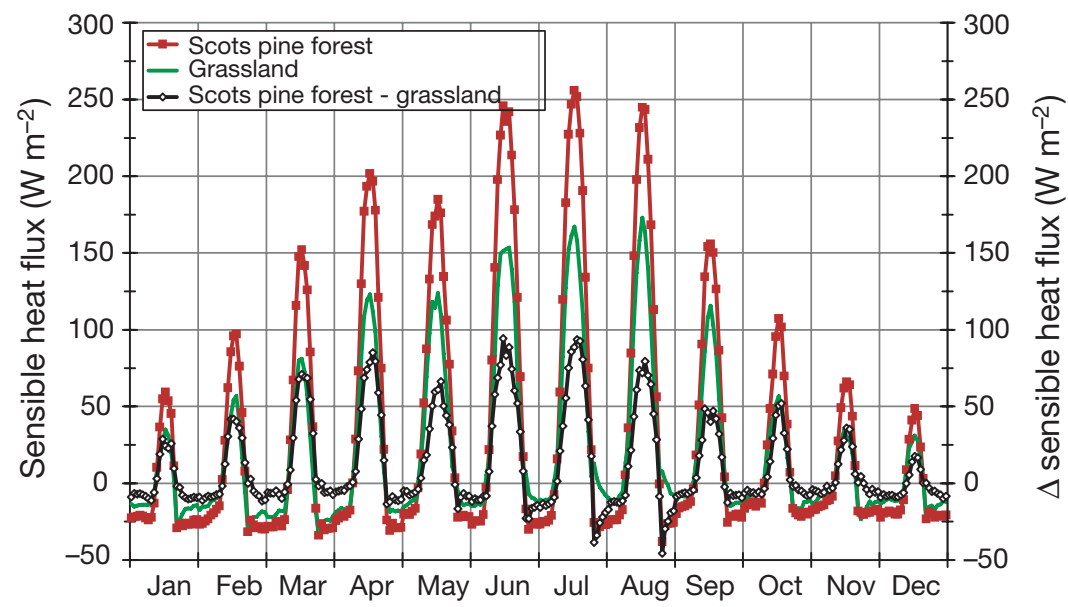

Fig. 9. Monthly means of diurnal variation of turbulent sensible heat flux of Scots pine forest and grassland during March 1992 to September 1996 bined to obtain as complete a time series of $H$ and $L E$ as possible. As a consequence of the sensitivity investigations, the following procedure was applied: first $H_{\mathrm{BREB}}$ and $L E_{\mathrm{BREB}}$ were calculated. In order to fill the remaining gaps $L E_{\mathrm{P} .-\mathrm{M}}$. was determined from Eq. (7) with $H_{\text {P.-M. }}$ as the residual flux. Finally $H_{\text {bulk }}$ was calculated from Eq. (11) with $L E_{\text {bulk }}$ as the residual flux. Hence all 3 methods imply a closed energy balance.

For the investigation period March 1992 to Septem1996, about $60 \%$ of the combined times series conmourly mean values of $H_{\mathrm{BREB}}$ and $L E_{\mathrm{BREB}}$. $H_{\mathrm{P}-\mathrm{M} \text {. }}$ $35 \%$ for the grassland site, respectively. $H_{\text {bulk }}$ and $L E_{\text {bulk }}$ represented $<5 \%$ of the hourly mean values for the Scots pine forest and $0.3 \%$ for the grassland site, respectively. Due to gaps in the original time series of meteorological data, the calculation of the turbulent heat fluxes was not possible for $10 \%$ of the hours for the Scots pine forest and for $5 \%$ for the grassland site. Due to the relatively low portion of heat fluxes that were determined according to the bulk approach, the underestimation of $H_{\text {bulk, }}$ which became apparent particularly for sunny conditions, can be discounted in the analysis of the complete time series.

The monthly averaged mean hourly values of the sensible heat flux $H$ were higher for the Scots pine forest than for grassland (Fig. 9). As expected, the differences were more pronounced during daytime than during nighttime. The highest difference (94 W m ${ }^{-2}$ ) occurred in July between 13:00 $\mathrm{h}$ and 14:00 h Central European Time (CET) and amounted to $37 \%$ of $H$ for the Scots pine forest. The larger negative values of $H$ for the Scots pine forest at night-time were induced by the production of cold air which drained down to the forest floor, resulting in stable thermal stratification within the stand. Due to the flatness of the area, the cold air accumulated within the stem layer until the net radiation became positive (Fig. 10).

Latent heat flux LE was higher (monthly averaged mean hourly values) for the Scots pine forest than for the grassland only from March to September (Fig. 11). The $L E$ differences were less pronounced than those for $H$. The peak difference $\left(39 \mathrm{~W} \mathrm{~m}^{-2}\right)$ was observed in August between 11:00 and 


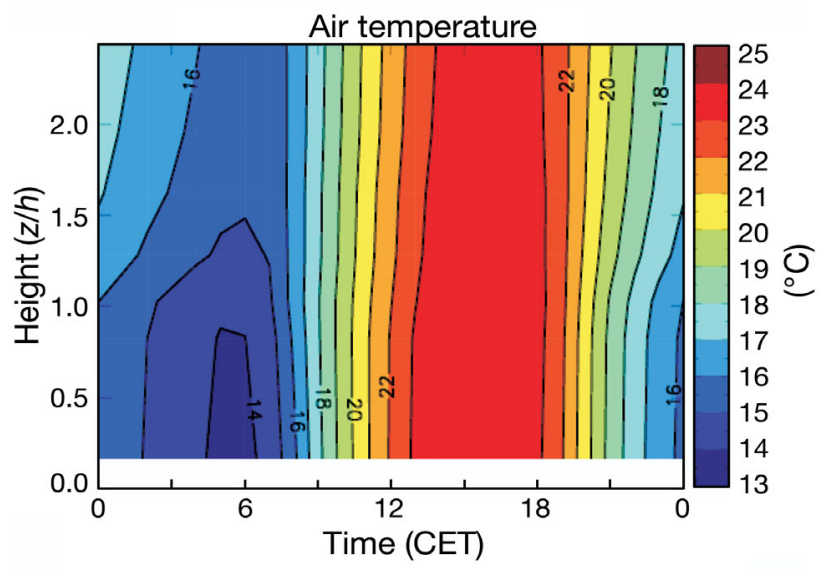

Fig. 10. Mean daily course of air temperature within and above the Scots pine forest in August, 1992 to 1996. CET: Central

European Time; $z$ : reference height; $h$ : mean stand height

12:00 h CET and amounted to $21 \%$ of $L E$ for the Scots pine forest. During nighttime, particularly from March to September, mean hourly $L E$ values of the grassland were more negative, indicating a stronger dewfall than for the Scots pine forest; this is also apparent from the increasing water vapour pressure (not shown). The effect was most pronounced $\left(49 \mathrm{~W} \mathrm{~m}^{-2}\right)$ in August between 19:00 and 20:00 h CET.

A comparative analysis of the energy fluxes from March to September shows higher monthly means of $Q^{*}, G+J, H$, and $L E$ for the Scots pine forest than for grassland (Fig. 12). In this period, the mean Bowen ratio $\beta$ varies between 0.72 (March) and 1.04 (August) for the Scots pine forest, and between 0.21 (March) and 1.05 (September) for the grassland, which indicates that the Scots pine forest converted a higher portion of the available energy into sensible heat flux than the grassland (see also Wicke \& Bernhofer 1996, Baldocchi et al.
Table 3. Normalised daytime $(07: 00 \mathrm{~h}$ to $19.00 \mathrm{~h}$ Central European Time) turbulent heat fluxes for grassland and Scots pine forest from March 1992 to September 1996. H: sensible heat flux, $L E$ : latent heat flux, $A E$ : available energy, $\beta$ : Bowen ratio. See end of Section 3.4 for definition of sufficient and low water supply

\begin{tabular}{|lcc|}
\hline & Grassland & Scots pine forest \\
\hline Mean & & \\
$H / A E$ & 0.42 & 0.52 \\
LE/AE & 0.58 & 0.48 \\
$\beta$ & 0.72 & 1.08 \\
Sufficient water supply & & \\
$H / A E$ & 0.40 & 0.50 \\
LE/AE & 0.60 & 0.50 \\
$\beta$ & 0.67 & 1.00 \\
Low water supply & & \\
$H / A E$ & 0.60 & 0.57 \\
LE/AE & 0.40 & 0.43 \\
$\beta$ & 1.50 & 1.33 \\
\hline
\end{tabular}

Table 4. Mean monthly precipitation $(P)$ and evaporation equivalence $(\mathrm{mm})$ of the net all-wave radiation $\left(Q^{*}=Q^{*} \times\right.$ $\Delta t / L\left[\mathrm{~W} \mathrm{~m}^{-2}\right]$, where $L$ is the heat of evaporation) for adjacent Scots pine forest and grassland in the period September 1991 to September 1996

\begin{tabular}{|c|c|c|c|c|}
\hline & \multicolumn{2}{|c|}{ Grassland } & \multicolumn{2}{|c|}{ Scots pine forest } \\
\hline & $P$ & $Q^{*}$ & $P$ & $Q^{*}$ \\
\hline January & 39 & -4 & 36 & -4 \\
\hline February & 27 & 8 & 23 & 12 \\
\hline March & 32 & 33 & 27 & 53 \\
\hline April & 58 & 75 & 51 & 104 \\
\hline May & 108 & 91 & 94 & 117 \\
\hline June & 77 & 124 & 71 & 155 \\
\hline July & 59 & 137 & 53 & 169 \\
\hline August & 69 & 99 & 62 & 129 \\
\hline September & 76 & 56 & 73 & 69 \\
\hline October & 59 & 23 & 57 & 29 \\
\hline November & 47 & 1 & 42 & 4 \\
\hline December & 48 & -7 & 44 & -8 \\
\hline
\end{tabular}

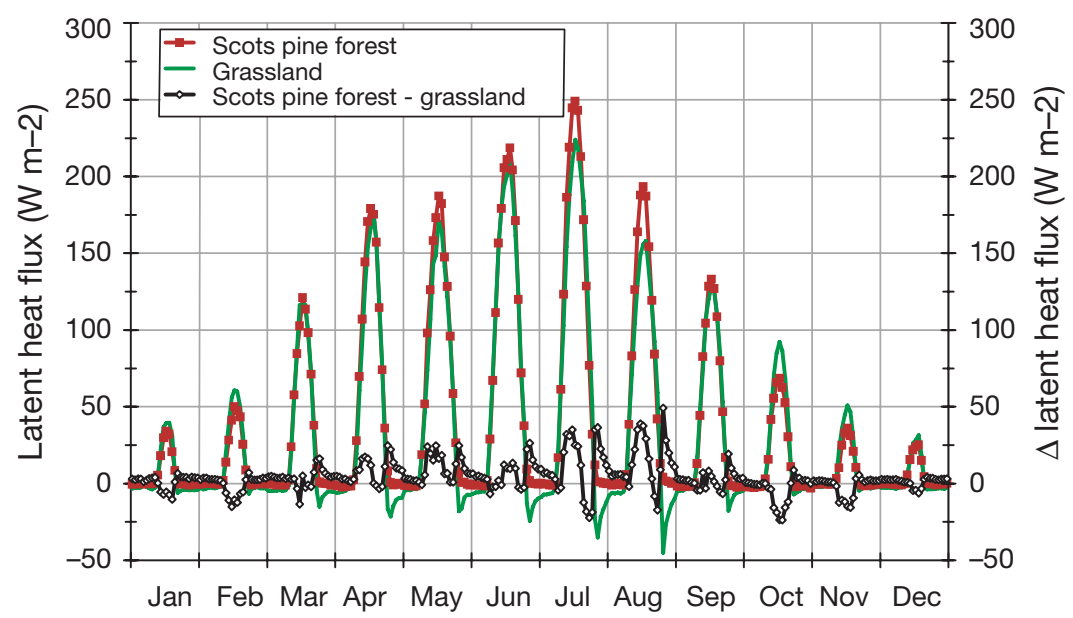

Fig. 11. Monthly means of diurnal variation of turbulent latent heat flux of Scots pine forest and grassland during March 1992 to September 1996
2004, Yamazaki et al. 2004). The relatively high mean $\beta$ value of grassland in August, which was about 1.2 times larger than during the other summer months and of the same magnitude as $\beta$ for the Scots pine forest, was caused by the drying of the grass. Since the aerodynamic conductivity of tall vegetation is very large, its evapotranspiration is limited by the canopy resistance particularly in summer if not enough water is available (Bernhofer et al. 1996).

Normalised by the available energy $A E$, the mean relative $H$ and $L E$ of grassland were lower and higher, respectively than for the Scots pine forest (shown in Table 3 for the daytime situation 07:00 to 19:00 h CET). The grassland site 

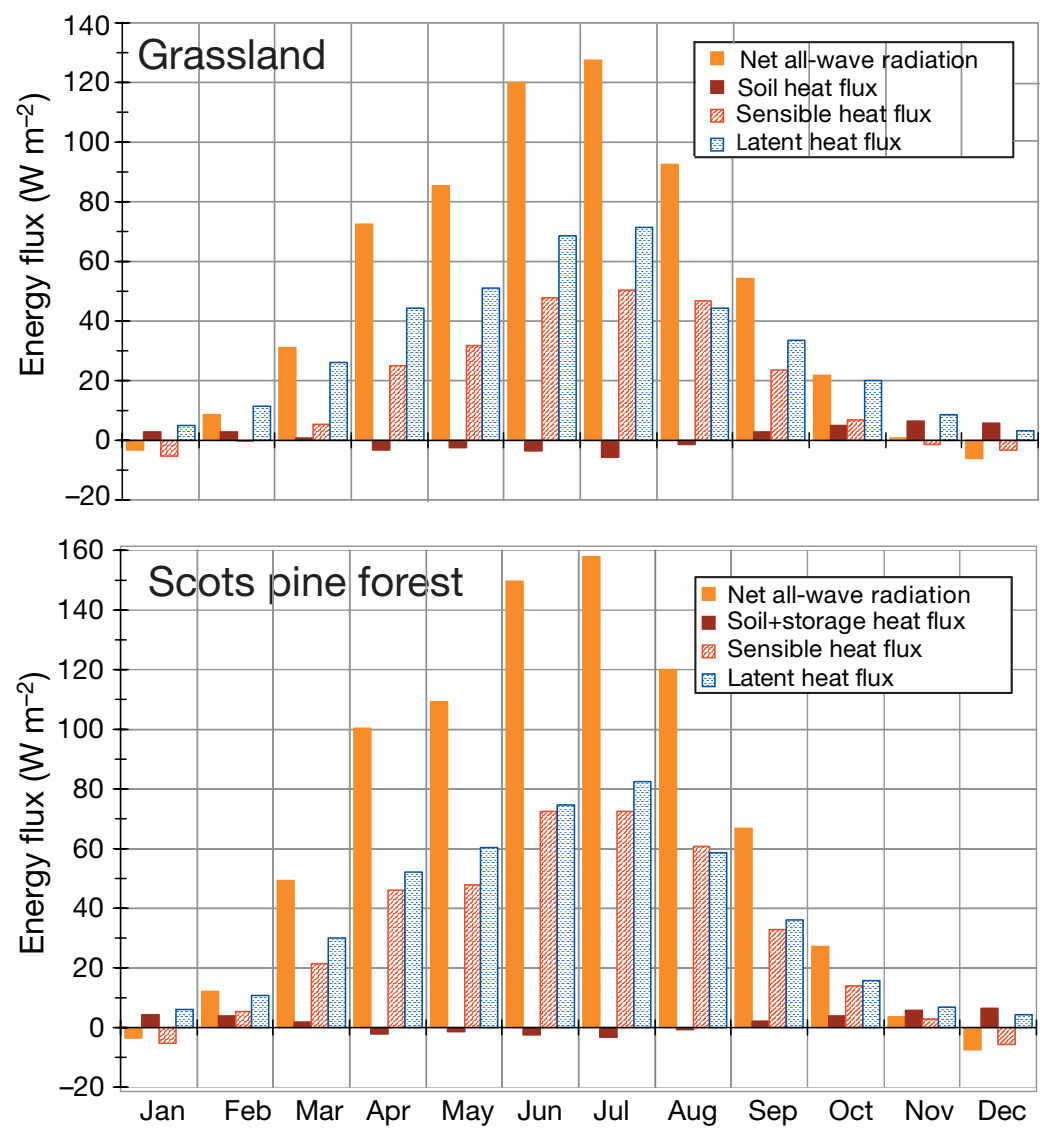

Fig. 12. Mean monthly values of net all-wave radiation and heat fluxes during March 1992 to September 1996

showed more pronounced differences between $L E / A E$ and $H / A E$ than the evergreen Scots pine forest. This phenomenon resulted mainly from the stomatal control (Polonio \& Soler 2000), which is characterised by a closure tendency during stress conditions, e.g. due to a reduced water supply. Averaged over the summer months of June, July, and August, the precipitation for the Scots pine forest reached only $41 \%$ of the evaporation equivalence of its net all-wave radiation, whereas it was $58 \%$ for the grassland site (Table 4).

To examine the impact of water supply in detail, $H / A E$ and $L E / A E$ were determined for sufficient and low water supply during daytime conditions (Table 3). Baldocchi (1997) defined water stress in vegetation i.e. low water supply - as the condition when (1) Priestly-Taylor's canopy drought stress index (CDSI, the ratio of cumulated precipitation to cumulated potential evaporation; Folken 2003) <1. In the present investigation 2 more conditions had to be met for low water supply: (2) the current CDSI had to be lower than the CDSI of the previous day and (3) the soil water content had to be below the permanent wilting point. In contrast, for periods of sufficient water supply, (1) CDSI is $>1$ for both land-use types, (2) the current
CDSI had to be higher than the CDSI of the previous day, and (3) the soil water content had to be above the permanent wilting point. Compared to mean conditions, the quota of $L E$ was lower during low water supply leading to $\beta$ values of 1.33 for the Scots pine forest and up to 1.50 for grassland (Table 3). During periods with sufficient water supply, half of $A E$ was converted into $L E$ for the Scots pine forest, while for grassland the proportion of $L E$ reached $60 \%$. These energetic conditions are reflected by $\beta$ values of 1.00 for the Scots pine forest and 0.67 for grassland.

\section{DISCUSSION}

Compared with other energy balance investigations, this study is one of the few analyses that compares the energy balance of 2 adjacent land-use types and is based on parallel meteorological measurements over a continuous period of $>4$ yr. Both experimental sites are located in the southern Upper Rhine Plain, which is characterised by a relatively warm and dry climate. The results, that the net all-wave radiation $Q^{*}$ and the available energy $A E$ of Scots pine forest were higher than for grassland, agree with previous investigations (Moore 1976, Baldocchi et al. 2004, Stiller et al. 2005). The surplus of $Q^{*}$ and $A E$ of the Scots pine forest compared to the values for the grassland have been quantified, both as a 4 yr average $\left(Q^{*}: 23 \%, A E: 24 \%\right)$ and for shorter periods.

Although the absolute mean monthly values of $H$ and $L E$ were higher for the Scots pine forest than for grassland from March to September, monthly means of $L E$ related to $A E$ were higher for grassland. This could be caused by the lower total transpiration capacity of evergreen conifers (evergreen conifers: 1400 to $1700 \mu \mathrm{mol} \mathrm{H} \mathrm{O} \mathrm{m}^{-2} \mathrm{~s}^{-1}$, grass species: 3000 to $450 \mu \mathrm{mol}$ $\mathrm{H}_{2} \mathrm{O} \mathrm{m}^{-2} \mathrm{~s}^{-1}$; Larcher 1994) and the reduced maximum leaf conductivities of Scots pine forests (conifers: $234 \pm$ $99 \mu \mathrm{mol} \mathrm{H}_{2} \mathrm{O} \mathrm{m}{ }^{-2} \mathrm{~s}^{-1}$, grass species: 200 to $1000 \mathrm{mmol}$ $\mathrm{H}_{2} \mathrm{O} \mathrm{m}^{-2} \mathrm{~s}^{-1}$; Körner 1994). On average, more available energy was converted into $L E$ than $H$ for both land-use types. These relations changed when only daytime conditions were considered and an additional differentiation between sufficient and low water supply was made. For daytime conditions, $L E / A E$ was also higher for grassland than for the Scots pine forest, but more available energy was converted into $H$ for the Scots 
pine forest and into $L E$ for grassland. Stiller et al. (2005) reported similar results for 2 sites (Scots pine forest and grassland on sandy soil) in northeastern Germany. Soil water content was the main steering factor for the partitioning of the turbulent heat fluxes.

In the case of sufficient water supply, the Bowen ratio $\beta$ was 1 for the Scots pine forest, indicating that equal proportions of the $A E$ were converted into $H$ and $L E$. For grassland, however, $60 \%$ of $A E$ was converted into $L E$ and only $40 \%$ into $H$. In the case of low water supply, more $A E$ was converted into $H$ for both landuse types (e.g. Gay et al. 1996, Jäggi 2003). The reduction of $L E / A E$ was more pronounced for grassland than for the Scots pine forest. This is probably caused by the different soil water content and root structure. According to Stiller et al. (2005) the soil water content at grassland sites in northeastern Germany is higher than that of forested sites in winter and spring, whereas at forested sites it is higher than at grassland sites in deeper soil layers during summer. The soil characteristics at the sites in northeastern Germany are comparable in depth and structure to those at Hartheim and Bremgarten. Furthermore, for the Hartheim forest recent sections revealed that some roots reach depths below the gravel layer and are therefore able to fetch water from deeper layers than grassland vegetation. As a consequence, the grassland dies and its evapotranspiration is interrupted. Therefore, more energy is transferred into the sensible heat flux (Baldocchi et al. 2004).

\section{CONCLUSIONS}

The performance of atmospheric models on various scales depends on a proper representation of surface processes, such as the partitioning of fluxes into energy balance components. This partitioning depends on soil properties, surface conditions, and topography (Polonio \& Soler 2000, Stiller et al. 2005).

This study increases the understanding of the influences of soil and vegetation on the surface energy balance by exploring 2 different land-use types (grassland, Scots pine forest) over a continuous period of more than 4 yr. Both experimental sites were close together in the southern Upper Rhine Plain and were investigated during the same time period. Hence, apart from convective precipitation events, there was no differential influence of weather conditions on the energy fluxes.

The climate in the southern upper Rhine plain is characterised by warm and dry weather conditions. Predicted air temperatures during summer show an increase of up to $3 \mathrm{~K}$ in Germany by 2070 (IPCC 2001, Schär et al. 2004, Enke et al. 2005). Hence, the area under investigation already reflects climate conditions as forecast by regional climate models for large parts of Germany. The results from this study can therefore be interpreted as indicative of grassland and pine forest energy balance in other regions in the future. Since the energy and water balance of covered surfaces is highly related to their net ecosystem exchange (NEE), this is also of major interest for ecosystem studies investigating the carbon budget of Scots pine forest or grassland.

Acknowledgements. This article is dedicated, on the occasion of his 75th birthday, to Prof. Dr. A. Kessler, former head of the Meteorological Institute, University of Freiburg, who was responsible for the Hartheim forest meteorological site for 2 decades. The authors thank W. Wicke for the pre-processing of the meteorological data.

\section{LITERATURE CITED}

Baldocchi DD (1997) Measuring and modelling carbon dioxide and water vapour exchange over a temperate broad-leaved forest during 1995 summer drought. Plant Cell Environ 20:1108-1122

Baldocchi DD, Xu L, Kiang N (2004) How plant functionaltype, weather, seasonal drought, and soil physical properties alter water and energy fluxes of an oak-grass savanna and an annual grassland. Agric For Meteorol 123:13-39

Beljaars ACM, Holtslag AAM (1991) A software library for the calculation of surface fluxes over land and sea. Environ Software 5:60-68

Bernhofer C, Blanford JH, Siegwolf R, Wedler M (1996) Applying single and 2 layer models to derive conductances of a Scots pine plantation from micrometeorological measurements. Theor Appl Climatol 53:95-104

Betts AK, Ball JH (1997) Albedo over boreal forests. J Geophys Res 102:28901-28910

Bounoua L, Defries R, Collatz GJ, Sellers P, Khan H (2002) Effects of land cover conversion on surface climate. Clim Change 52:29-64

Businger J, Wyngaard J, Izumi Y, Bradley E (1971) Flux profile relationships in the atmospheric surface layer. J Atmos Sci 28:181-189

Dyer AJ (1974) A review of flux-profile relationships. Boundary-Layer Meteorol 7:363-372

Enke WT, Deutschländer T, Schneider F, Küchler W (2005) Results of five regional climate studies applying a weather pattern based downscaling method to ECHAM4 climate simulations. Meteorol Z 14:247-258

Flanagan LB, Wever LA, Carlson PJ (2002) Seasonal and interannual variation in carbon dioxide exchange and carbon balance in a northern temperate grassland. Glob Change Biol 8:599-615

Foken T (2003) Angewandte Meteorologie. Mikrometeorologische Methoden. Springer-Verlag, Berlin

Garrat JR (1992) The atmospheric boundary layer. Cambridge University Press, Cambridge

Gay LW, Vogt R, Kessler A (1996) The May-October energy budget of a Scots pine plantation at Hartheim, Germany. Theor Appl Climatol 53:79-94

Hädrich F (1979) Der Wasserhaushalt einer ZweischichtPararendzina unter Kiefernjungbeständen im Trockengebiet am südlichen Oberrhein. Mitt Dtsch Bodenkundl Ges 29:149-158 
Imbery F (2005) Langjährige Variabilität der aerodynamischen Oberflächenrauhigkeit und Energieflüsse eines Kiefernwaldes in der südlichen Oberrheinebene (Hartheim). Ber Meteorol Inst Univ Freiburg 14

IPCC (Intergovernmental Panel on Climate Change) (2000) Land use, land-use change, and forestry. Cambridge University Press, Cambridge

IPCC (Intergovernmental Panel on Climate Change) (2001) IPPC third assessment report. Climate change 2001: the scientific basis. Summary for policymakers. IPCC, Geneva

Jäggi M (2003) Mikrometeorologische Bestimmung des Energiehaushaltes einer Magerwiese in komplexem Gelände. MCR-Lab, Basel, Stratus no. 8

Kalthoff N, Fiedler F, Kohler M, Kolle O, Mayer H, Wenzel A (1999) Analysis of energy balance components as a function of orography and land use and comparison of results with the distribution of variables influencing local climate. Theor Appl Climatol 63:65-84

Kessler A, Jaeger L (1999) Long-term changes in net radiation and its components above a pine forest and a grass surface in Germany. Int J Climatol 19:211-226

Körner C (1994) Leaf diffuse conductances in the major vegetation types of the globe. In: Schulze ED, Caldwell MM (eds) Ecophysiology of photosynthesis. Springer, Berlin, p 463-490

Köstner B, Biron P, Siegwolf R, Granier A (1996) Estimates of water vapour flux and canopy conductance of Scots pine and the three level utilizing different xylem sap flow methods. Theor Appl Climatol 53:105-113

Larcher W (1994) Ökophysiologie der Pflanzen. Ulmer, Stuttgart

Launiainen J, Vihma T (1990) Derivation of turbulent surface fluxes - an iterative flux-profile method allowing arbitrary observing heights. Environ Software 5:113-124

Lhomme JP, Chebouni A, Monteny B (2000) Sensible heat flux-radiometric surface temperature relationship over sparse vegetation: parameterizing $\mathrm{kB}^{-1}$. Boundary-Layer Meteorol 97:431-457

Mayer H, Fernbach G, Jaeger L, Kessler A, Matzarakis A, Redepenning D (2000) Forstmeteorologische Messstelle Hartheim des Meteorologischen Institutes der Universität Freiburg. Ber Meteorol Inst Univ Freiburg 5:55-84

Moore CJ (1976) A comparative study of radiation balance above forest and grassland. Q J R Meteorol Soc 102: 889-899

Ohmura HR (1982) Objective criteria for rejecting data for Bowen ratio flux calculations. J Appl Meteorol 21:595-598

Oliphant AJ, Grimmond CSB, Zutter HN, Schmid HP and 5 others (2004) Heat storage and energy balance fluxes for a temperate deciduous forest. Agric For Meteorol 126: 185-201

Polonio D, Soler MR (2000) Surface fluxes estimation over agricultural areas. Comparison of methods and the effects

Editorial responsibility: Christopher de Freitas, Auckland, New Zealand of land surface inhomogeneity. Theor Appl Climatol 67: $65-79$

Rana G, Katerji N (1998) A measurement based sensitivity analysis of the Penman-Monteith actual evapotranspiration model for crops of different height and in contrasting water status. Theor Appl Climatol 60:141-149

Read DJ, Beerling DJ, Cannel M, Cox P and 7 others (2001) The role of land carbon sinks in mitigating global climate change. Policy document 10/01, The Royal Society, London

Rost J (2004) Vergleichende Analyse der Energiebilanz zweier Untersuchungsflächen der Landnutzungen 'Grasland' und 'Wald' in der südlichen Oberrheinebene. Ber Meteorol Inst Univ Freiburg 9

Schaphoff S, Lucht W, Gerten D, Sitch S, Cramer W, Prentice IC (2006) Terrestrial biosphere carbon storage under alternative climate projections. Clim Change 74 (doi: 10.1007/s10584-005-90002-5)

Schär C, Vidale PL, Lüthi D, Frei C, Häberli C, Liniger MA, Appenzeller C (2004) The role of increasing temperature variability in European summer heatwaves. Nature 427: $332-336$

Schott R (1980) Untersuchungen über die Energiehaushaltskomponenten in der atmosphärischen Grenzschicht am Beispiel eines Kiefernbestandes in der Oberrheinebene (Hartheim/Rh.). Ber Deutscher Wetterdienst 153

Stiller B, Beyrich F, Hollaz G, Leps JP, Richter S, Weisensee U (2005) Continuous measurements of the energy budget components at a pine forest and at a grassland site. Meteorol Z 14:137-142

Stull RB (1988) An introduction to boundary layer meteorology. Kluwer, Dordrecht

Tchebakova NM, Kolle O, Zolotoukhine D, Arneth A and 5 others (2002) Inter-annual and seasonal variations of energy and water vapour fluxes above a Pinus sylvestris forest in the Siberian middle taiga. Tellus 54B:537-551

Troufleau D, Lhomme JP, Monteny B, Vidal A (1997) Sensible heat flux and radiometric surface temperature over sparse Sahelian vegetation. I. An experimental analysis of the $\mathrm{kB}^{-1}$ parameter. J Hydrol 188-189:815-838

Vogt R, Bernhofer C, Gay LW, Jaeger L, Parlow E (1996) The available energy over a Scots pine plantation: what's up for partitioning. Theor Appl Climatol 53:23-31

Wellpott A, Imbery F, Schindler D, Mayer H (2005) Simulation of drought for a Scots pine forest (Pinus sylvestris L.) in the southern Upper Rhine Plain. Meteorol Z 14:143-150

Wicke W, Bernhofer C (1996) Energy balance comparison of the Hartheim forest and an adjacent grassland site during the HartX experiment. Theor Appl Climatol 53:49-58

Yamazaki T, Yabuki H, Ishii Y, Ohta T, Ohata T (2004) Water and energy exchanges at forests and a grassland in Eastern Siberia evaluated using a one-dimensional land surface model. J Hydrometeorol 5:504-515

Submitted: September 1, 2005; Accepted: January 17, 2006

Proofs received from author(s): March 29, 2006 